\title{
OCCURRENCE, CRYSTALLOGRAPHY AND CHEMISTRY OF THE FLUOCERITE-BASTNAESITE-CERIANITE INTERGROWTH FROM THE FJÄLSKÄR GRANITE, SOUTHWESTERN FINLAND
}

\author{
SEPPO I. LAHTI and VELI SUOMINEN
}

\begin{abstract}
LAHTI, SEPPO I. and SUOMINEN, VELI, 1988: Occurrence, crystallography and chemistry of the fluocerite-bastnaesite-cerianite intergrowth from the Fjälskär granite, southwestern Finland. Bull. Geol. Soc. Finland 60, Part 1, 45-53.

White crystals composed mainly of fluocerite were identified during separation of the accessory minerals of the Middle Proterozoic Fjälskär granite, southwestern Finland. Detailed X-ray diffraction and microprobe studies showed that the mineral is intergrown with bastnaesite and cerianite.

X-ray single crystal studies reveal that fluocerite-(Ce) $(\mathrm{a}=7.11 \AA$, $\mathrm{c}=7.28 \AA$, space group $\mathrm{P} 6_{3} \mathrm{mcm}$ ) forms in the mineral syntaxial intergrowth with bastnaesite(Ce) $\left(\mathrm{a}=7.11 \AA, \mathrm{c}=9.74 \AA\right.$, space group $\left.\mathrm{P}_{2} \mathrm{c}\right)$. The cerianite phase $(\mathrm{a}=5.45 \AA$, space group $\mathrm{Fm} 3 \mathrm{~m}$ ) is intergrown with fluocerite-bastnaesite in a more complex way. The $\{0001\}$ plane of fluocerite-bastnaesite is parallel to the $\{111\}$ plane of cerianite and the $\{1000\}$ plane of fluocerite-bastnaesite is parallel to the (110) or corresponding plane of cerianite.

The fluocerite-bastnaesite-cerianite intergrowth is dominated by LREEs, especially $\mathrm{Ce}$, La and $\mathrm{Nd}$. Its composition varies slightly; pure separate phases cannot be distinguished with the microprobe. Zircon and fluorite associated with fluocerite have minor REEs (below $0.3 \mathrm{wt} \% \mathrm{RE}_{2} \mathrm{O}_{3}$ ).

The Fjälskär granite is exceptionally enriched in REEs mainly incorporated in fluocerite and associated REE minerals. The $\mathrm{CO}_{2}$-bearing fluids altered fluocerite to bastnaesite as crystallization drew to an end in the rock. Separation of the cerianite phase was due to later oxidation of $\mathrm{Ce}^{3+}$. Because of structural and chemical similarities, the crystallographic axes of the various phases are preferentially oriented in the intergrowth.
\end{abstract}

Key words: granites, fluocerite, bastnaesite, cerianite, intergrowths, unit cell, chemical composition, rare earths, Fjälskär, Houtskär, Finland.

Seppo I. Lahti and Veli Suominen: Geological Survey of Finland, SF-02150 Espoo, Finland.

\section{Introduction}

During separation of the heavy accessory minerals of the Fjälskär granite, southwestern Finland, for age determination (sample no. A287, Fjärdskär, Houtskär, map 1041 07, Finnish national grid coordinates $\mathrm{x}=6689800, \mathrm{y}=$ $1520860)$ a pinkish white mineral was encoun- tered that was tentatively identified as fluocerite $(\mathrm{Ce}, \mathrm{La}, \mathrm{Nd} \ldots) \mathrm{F}_{3}$. However, the X-ray powder diffraction films of the mineral always showed several strong additional lines, indicating that the crystals are intergrowths composed of different mineral phases.

The Fjälskär granite forms a roundish stock about $5 \mathrm{~km}$ in diameter. The bulk of the intru- 
sion is composed of porphyritic biotite-muscovite granite. K-feldspar phenocrysts, $1-3 \mathrm{~cm}$ long, appear in the rock, but near the contacts the grain size decreases and the granite is less porphyritic. The contact between the granite and the surrounding rocks is sharp and the granite cuts the schistosity of the surrounding Svecokarelian gneisses. On the basis of the petrological evidence, Sederholm (1934) included the Fjälskär granite in the postorogenic rapakivi granite group of southwestern Finland. Later, Ehlers and Bergman (1984) and Bergman (1986) discussed the intrusion mechanism of the granite in detail, and also gave a short petrographic description of the rock. Recent studies assign a U-Pb zircon age of $1579 \pm 13$ Ma to the granite (Suominen 1988, in prep.) and thus support Sederholm's assumption.

Like the last intrusion phases of the Finnish rapakivi granites, the rock has fluorite and topaz as accessory minerals (cf. Vorma 1976; Haapala 1977). Thin, often irregular, pegmatite dykes containing abundant blue green topaz and fluorite, and muscovite-greisen dykes appear in the marginal parts of the stock, indicating that the residual melt was enriched in volatiles, fluo- rine in particular. Chemical analyses of the granite show exceptionally high concentrations of REEs mainly due to fluocerite and associated REE minerals.

The fluocerite-intergrowth from the Fjälskär granite was studied in detail in a Buerger X-ray precession camera and with X-ray powder diffraction methods with a view to establishing the different phases of the mineral and to confirm the identification of fluocerite. Because of the small amount of sample, the mineral was analysed only with the microprobe. Of the authors, S.I.L. is responsible for the $\mathrm{X}$-ray diffraction and other mineralogical studies and V.S. for the description of the granite and its geology.

\section{Occurrence of the fluocerite intergrowth}

The fluocerite intergrowth was first encountered in the heavy mineral fraction of the rock as faint, pinkish white small grains with columbite, topaz, zircon, bastnaesite, fluorite, apatite, galena and molybdenite. After careful examination under stereomicroscope the mineral was ob-

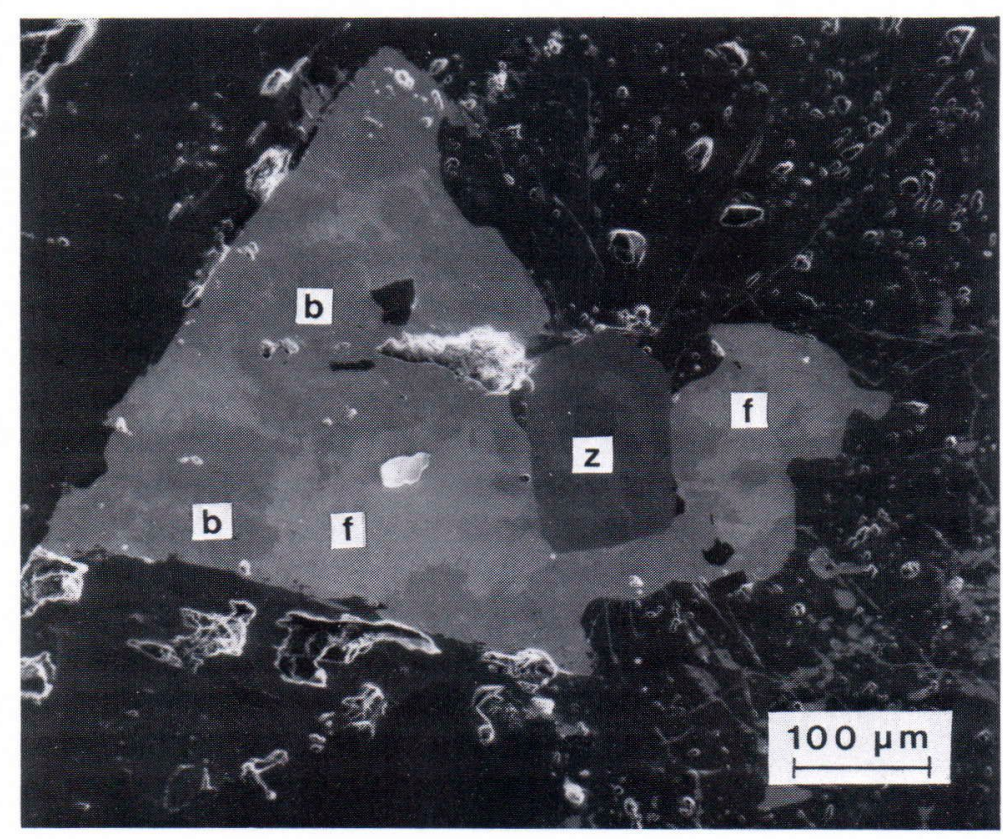

Fig. 1. Secondary electron image of an altered fluocerite crystal (f) replaced by bastnaesite (b, dark grey). The angular crystal partly surrounded by the bastnaesite and fluocerite intergrowth is zircon (z). The black background is composed of other silicates. 
served in a polished slab of the granite. In this specimen the fluocerite intergrowth occurs as a white, angular grain about $0.5 \mathrm{~mm}$ in diameter replaced by light brown bastnaesite-(Ce). The surrounding minerals are zircon, fluorite, biotite, quartz, K-feldspar and plagioclase (Fig. 1).

Thin section and X-ray studies show that the reddish $\mathrm{K}$-feldspar associated with the fluocerite intergrowth is cross-twinned micro- or cryptoperthitic intermediate microcline or orthoclase. Quartz occurs in the rock either as irregular, small crystals between feldspars or as large, separate, short-prismatic crystals that are readily recognizable on the surface of the rock on the basis of the bluish colour. The core of the plagioclase (oligoclase) crystal laths is often slightly seritized and saussuritized, but the crystals are rimmed by fresh, unaltered plagioclase of the second generation. Brown iron-rich biotite predominate in the granite, but the rock also contains some muscovite.

\section{X-ray single crystal studies}

The Fjälskär fluocerite intergrowth was studied using a Buerger X-ray precession camera and a small crystal fragment (diameter $0.1-0.2 \mathrm{~mm}$ ). The c-axis 0-level precession photographs show the spots of two separate mineral phases, but the a-axis 0-level photographs indicate that three different phases are present and that certain axes of the two phases are equal in length. The reciprocal lattice point rows are parallel or coalesce indicating that the different phases are oriented in certain directions in the intergrowth.

Careful scrutiny of the photographs showed that the main phase of the intergrowth is fluocerite. First a-axis and later c-axis $0-, 1$ - and 2- level precession photographs of fluocerite were taken. Film shrinkage was determined on the spots of an oriented silicon crystal. Zr-filtered Mo radiation $(\lambda \mathrm{MoK} \alpha=0.7107 \AA)$ was used in the studies.

The unit cell dimensions of the fluocerite phase measured from the precession camera films are $\mathrm{a}=7.11 \AA, \mathrm{c}=7.28 \AA$ and the space group $\mathrm{P}_{3}$ mcm (no. 193, hh01:1 = 2n, $0001: 1=$ $2 \mathrm{n})$. The mineral is therefore fluocerite-(Ce). The unit cell is comparable to that of fluocerite$(\mathrm{Ce}, \mathrm{La})$ given in the JCPDS-card 2-529 $(\mathrm{a}=7.12$ $\AA$ and $\mathrm{c}=7.28 \AA$ ) and to that of Nigerian fluocerite-(Ce) $(\mathrm{a}=7.130 \AA$ and $\mathrm{c}=7.298 \AA)$ as described by Styles and Young (1983). The unit cell dimensions of fluocerite-(La) shown in the JCPDS-card 32-483 are slightly greater.

Fluocerite is syntaxially intergrown with another hexagonal phase, which corresponds well with bastnaesite in unit cell and symmetry. Both the a-axes and the c-axes of the minerals are parallel to each other. The spots of the bastnaesite phase cannot be detected in the c-axis 0-level photograph, because the length of the a-axis of both fluocerite and bastnaesite and the systematic extinctions in the c-axis photographs are the same. The unit cell dimensions of bastnaesite measured from the precession photographs are $\mathrm{a}=7.11 \AA$ and $\mathrm{c}=9.74 \AA$; the space group is P62c (no. 190, 0001: 1 = 2n and hh01: $1=$ $2 \mathrm{n}$ and hh2hl: $1=2 \mathrm{n}$ ).

The unit cell dimensions of bastnaesite reported in the literature vary substantially, depending on the composition. The cell data on the mineral studied correspond to those on bastnaesite-(Ce) as given in JCPDS-card 11-340 (a = 7.129 $\AA$, c $=9.774 \AA)$ and bastnaesite- $(\mathrm{Ce}, \mathrm{La})(\mathrm{a}=7.12 \AA$, $\mathrm{c}=9.80 \AA$ ) studied by Jansen et al. (1959). The unit cell of hydroxylbastnaesite-(Ce,La) $(\mathrm{a}=$ $7.23 \AA$ and $c=9.98 \AA$, JCPDS-card 17-503) is slightly larger and that of bastnaesite-(Y) much smaller $(a=6.57 \AA, c=9.42 \AA$, JCPDS-card 25-1009) than the unit cell of the bastnaesite intergrown with fluocerite.

In addition to fluocerite and bastnaesite, the intergrowth has a third phase for which the Xray powder pattern indicates cubic symmetry with fluorite-derivative structure. Its strongest reflections correspond closely to those of cerianite. The computation of the unit cell dimension from the $\mathrm{X}$-ray powder pattern on the basis of the five 
strongest reflections (indexed as 111, 200, 220, 311 and 331) gave $\mathrm{a}=5.45 \AA$. Later interpretation of the precession photographs shows the same unit cell dimension, and the space group is in accordance with Fm3m (no. 225, hkl: $\mathrm{h}+\mathrm{k}$ $=2 \mathrm{n}, \mathrm{k}+1=2 \mathrm{n} ; 1+\mathrm{h}=2 \mathrm{n}$; hhl $(1+\mathrm{h}=2 \mathrm{n})$; $0 \mathrm{kl}(\mathrm{k}, 1=2 \mathrm{n}))$.

The symmetry, the unit cell and the composition of the intergrowth indicate that the third phase is cerianite $\mathrm{CeO}_{2}$ or a corresponding mixture of $\mathrm{Ce}$ and other REE oxides. The unit cell dimension of pure synthetic $\mathrm{CeO}_{2}$ is slightly shorter, i.e. $\mathrm{a}=5.41 \AA$ (see JCPDS-card 34-394). Natural cerianites are usually mixtures of Ce and other REE oxides and therefore their unit cell dimensions may vary considerably. Gurov et al. (1975) have reported a cubic cerianite phase with $\mathrm{a}=5.45 \AA$, and Styles and Young (1983) a cerianite phase with $\mathrm{a}=5.46 \AA$, both occurring in association with fluocerite. The unit cell dimension also agrees well with that of synthetic cerium neodymium oxide with $\mathrm{a}=5.46 \AA$ as reported in JCPDS-card 28-266.

The $\mathrm{d}$-values of the cerianite reflections along the $c^{*}$-axis of fluocerite-bastnaesite correspond

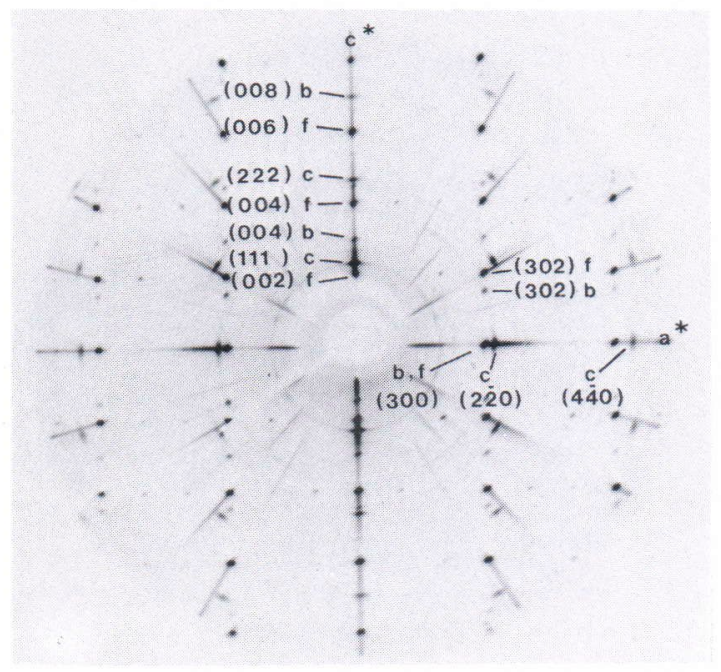

Fig. 2. Interpretation of the b-axis 0-level precession photograph of fluocerite. The figure indicates that the mineral is an intergrowth of fluocerite (f), bastnaesite (b) and cerianite (c) phases. See details in text. $\mathrm{Zr}$-filtered Mo radiation. to the computed d-values of the (111) (d 3.147), (222) (d 1.574) and (333) (d 1.049) reflections (Fig. 2). Therefore the $\{0001\}$ plane of fluocerite and bastnaesite is parallel to the $\{111\}$ plane of cerianite (the triad axis of cerianite is parallel to the hexad axis of fluocerite-bastnaesite). The dvalues of the cerianite reflections along the $\mathrm{a}^{*}$-axis of fluocerite- bastnaesite compare well with the computed d-values of the (220) (d 1.927) and (440) (d 0.964) reflections, indicating that the (110) plane (or a corresponding plane in the same zone, i.e. $\overline{1} 10,01 \overline{1}, 0 \overline{1} 1,10 \overline{1}, \overline{1} 01)$ of cerianite is parallel to the $\{1000\}$ plane of fluocerite-bastnaesite (Fig. 2).

\section{X-ray powder diffraction studies}

An X-ray powder pattern was subsequently recorded from the mineral in a Debye-Scherrer camera (diam. $114.3 \mathrm{~mm}$ ) using $\mathrm{Ni}$-filtered $\mathrm{Cu}$ radiation $(\lambda \mathrm{CuK} \alpha=1.5418 \AA)$. The powder diffraction pattern of the crystal is given in Table 1. All possible d-values of each three phases observed in the precession photographs were computed. The d-values measured from the powder photograph were indexed with the aid of the computed d-values. Table 1 shows that the reflections of the fluocerite intergrowth derive mainly from the fluocerite-phase. Several cerianite lines, but only some reflections of the bastnaesite phase, can be conclusively identified in the X-ray powder pattern; most of the reflections of the three phases coalesce and form a sum line in the Debye-Scherrer camera film. The measured and computed d-values are close to each other, and the intensities of the reflections in the X-ray powder pattern and the single crystal photographs correspond well with each other.

In Table 1 the X-ray powder pattern of the Fjälskär fluocerite intergrowth is compared with the X-ray powder pattern given by Gurov et al. (1975) for fluocerite altered to cerianite. The chemical composition of both intergrowths is also close to each other. Some lines in the X-ray pow- 
Table 1. X-ray powder diffractogram of fluocerite intergrowth (fluocerite altered to cerianite and bastnaesite?) reported by Gurov et al. (1975, Table 3) compared with that of the Fjälskär fluocerite intergrowth. The computed d-values for the Fjälskär bastnaesite and the cerianite phase intergrown with fluocerite are given separately. $\mathrm{B}=$ broad line.

\begin{tabular}{|c|c|c|c|c|c|c|c|c|}
\hline 1 & 2 & 3 & 4 & & 5 & & 6 & 7 \\
\hline 5.0 & 2 & & & & & 5.20 & (101) & \\
\hline 4.10 & 1 & & & & & 3.82 & (102) & \\
\hline 3.70 & 2 & 3.655 & 6 & 3.64 & $(002)$ & & & \\
\hline 3.60 & 4 & 3.578 & 6 & 3.56 & (110) & 3.56 & (119) & \\
\hline 3.47 & 2 & & & & & & & \\
\hline 3.21 & 7 & 3.225 & 10 & 3.19 & (111) & 3.25 & $(003)$ & \\
\hline 3.15 & 10 & 3.150 & 10 & & & & & 3.147 (111) \\
\hline 3.00 & 1 & & & 3.080 & (200) & & & \\
\hline 2.87 & 1 & 2.921 & 2 & & & 2.871 & (112) & \\
\hline 2.72 & 3 & 2.727 & 5 & & & & & $2.726(002)$ \\
\hline 2.55 & 1 & 2.564 & 2 & 2.543 & (112) & & & \\
\hline 2.43 & 1 & & & & & 2.435 & (004) & \\
\hline 2.06 & 5 & 2.065 & 8 & 2.052 & $(300)$ & 2.052 & $(300)$ & \\
\hline 2.020 & 2 & 2.015 & 8 & 2.004 & (113) & 2.009 & (114) & \\
\hline 1.925 & 7 & 1.925 & 8 & & & & & $1.927(220)$ \\
\hline \multirow[t]{2}{*}{1.804} & 3 & 1.797 & 5 & $\begin{array}{l}1.820 \\
1.789\end{array}$ & $\begin{array}{l}(004) \\
(302)\end{array}$ & & & \\
\hline & & 1.734 & 4 & 1.727 & (221) & & & \\
\hline 1.644 & 6 & 1.643 & 6 & 1.620 & (114) & 1.640 & (221) & $1.643(311)$ \\
\hline 1.571 & 1 & 1.570 & 2 & 1.567 & (303) & 1.569 & (304) & 1.574 (222) \\
\hline 1.507 & & & & & & 1.511 & (313) & \\
\hline 1.445 & 3 & 1.441 & 3 & 1.434 & (223) & & & \\
\hline 1.362 & 1 & $1.365 \mathrm{~B}$ & 3 & 1.362 & (304) & 1.360 & (224) & $1.363(400)$ \\
\hline 1.329 & 2 & 1.329 & 3 & 1.321 & (411) & & & \\
\hline 1.305 & 1 & & & & & 1.301 & (404) & \\
\hline 1.250 & 5 & 1.251 & 2 & 1.245 & (314) & & & $1.251(331)$ \\
\hline 1.217 & 2 & 1.219 & 1 & 1.213 & (006) & 1.218 & (008) & 1.219 (204) \\
\hline 1.154 & 1 & $1.183 \mathrm{~B}$ & 2 & 1.185 & (330) & 1.185 & (330) & \\
\hline 1.130 & 2 & 1.133 & 2 & 1.129 & (006) & & & \\
\hline
\end{tabular}

Measured d-values (1) and intensities (2) of the reflections for the altered fluocerite reported by Gurov et al. (1975).

Measured d-values (2) and intensities (4) of the reflections for the fluocerite intergrowth from the Fjälskär granite.

Calculated d-values (5) and hkl-combinations for the Fjälskär fluocerite.

Calculated d-values (6) and hkl-combinations for the bastnaesite intergrown with fluocerite.

Calculated d-values (7) and hkl-combinations for the cerianite intergrown with fluocerite.

der pattern reported by Gurov et al. (1975) might also be due to bastnaesite (see Table 1).

\section{Chemistry of the fluocerite intergrowth and associated REE-bearing minerals}

The Fjälskär fluocerite intergrowth, together with the associated bastnaesite, fluorite and zircon, was analysed at the Geological Survey of Finland using a JEOL JXA-733 Super Probe equipped with an energy dispersive spectrometer system (EDS). The specifications for the quantitative analyses were $15 \mathrm{kV}$ accelerating voltage, $25 \mathrm{nA}$ probe current and a beam diameter of about $1 \mu \mathrm{m}$. Synthetic $(\mathrm{RE}) \mathrm{F}_{3}$ and monazite were used as standards. The data were processed with a standard ZAF (atomic number, absorption and fluorescence) correction program.

A fluocerite intergrowth partly surrounded and replaced by light brown bastnaesite was analysed from a polished section. First a set of X-ray, secondary electron (SEI) and backscattered electron (BEI) images was produced to test the 
Table 2. Chemical composition (wt \%) of the Fjälskär bastnaesite $(1-5)$ and fluocerite intergrowth $(6-12)$. Partial microprobe analyses by Bo Johanson.

\begin{tabular}{|c|c|c|c|c|c|c|}
\hline & 1 & 2 & 3 & 4 & 5 & 6 \\
\hline $\mathrm{Ce}_{2} \mathrm{O}_{3}$ & 29.0 & 30.8 & 33.1 & 34.2 & 36.5 & 39.4 \\
\hline $\mathrm{La}_{2} \mathrm{O}_{3}$ & 19.8 & 20.4 & 17.4 & 20.3 & 20.8 & 30.1 \\
\hline $\mathrm{Nd}_{2} \mathrm{O}_{3}$ & 7.5 & 4.7 & 5.6 & 5.6 & 5.6 & 5.7 \\
\hline $\mathrm{Y}_{2} \mathrm{O}_{3}$ & 0.0 & 2.0 & 1.3 & 1.8 & 0.0 & 0.1 \\
\hline $\mathrm{Yb}_{2} \mathrm{O}_{3}$ & 0.0 & 0.0 & 0.2 & 0.2 & 0.0 & 0.0 \\
\hline $\mathrm{CaO}$ & 0.5 & 5.1 & 2.7 & 3.6 & 0.5 & 0.3 \\
\hline $\mathrm{F}$ & 3.3 & 3.5 & 3.4 & 3.3 & 3.6 & 12.5 \\
\hline \multicolumn{7}{|c|}{ REEs + Y computed to 100} \\
\hline $\mathrm{Ce}$ & 51.58 & 52.49 & 56.91 & 54.41 & 57.90 & 52.33 \\
\hline $\mathrm{La}$ & 35.41 & 34.94 & 30.06 & 32.48 & 33.35 & 40.22 \\
\hline $\mathrm{Nd}$ & 13.01 & 7.71 & 9.42 & 8.62 & 8.65 & 7.32 \\
\hline $\mathrm{Y}$ & 0.00 & 4.86 & 3.33 & 4.23 & 0.10 & 0.13 \\
\hline \multirow[t]{2}{*}{$\mathrm{Yb}$} & 0.00 & 0.00 & 0.28 & 0.26 & 0.00 & 0.00 \\
\hline & 7 & 8 & 9 & 10 & 11 & 12 \\
\hline $\mathrm{Ce}_{2} \mathrm{O}_{3}$ & 43.5 & 45.7 & 46.5 & 47.6 & 49.6 & 51.6 \\
\hline $\mathrm{La}_{2} \mathrm{O}_{3}$ & 31.6 & 31.6 & 27.6 & 33.3 & 25.9 & 28.6 \\
\hline $\mathrm{Nd}_{2} \mathrm{O}_{3}$ & 5.0 & 5.3 & 5.2 & 5.3 & 7.7 & 8.6 \\
\hline $\mathrm{Y}_{2} \mathrm{O}_{3}$ & 0.1 & 0.0 & 0.1 & 0.0 & 0.1 & 0.1 \\
\hline $\mathrm{Yb}_{2} \mathrm{O}_{3}$ & 0.0 & 0.0 & 0.1 & 0.0 & 0.0 & 0.0 \\
\hline $\mathrm{CaO}$ & 0.4 & 0.3 & 0.5 & 0.3 & 0.4 & 0.4 \\
\hline $\mathrm{F}$ & 12.0 & 11.3 & 10.1 & 12.8 & 11.4 & 11.4 \\
\hline \multicolumn{7}{|c|}{ REEs + Y computed to 100} \\
\hline $\mathrm{Ce}$ & 54.20 & 55.23 & 58.34 & 55.17 & 59.53 & 57.99 \\
\hline $\mathrm{La}$ & 39.63 & 38.46 & 34.91 & 38.86 & 31.30 & 32.35 \\
\hline $\mathrm{Nd}$ & 6.05 & 6.27 & 6.38 & 5.97 & 8.98 & 9.48 \\
\hline Y & 0.12 & 0.04 & 0.25 & 0.00 & 0.20 & 0.18 \\
\hline $\mathrm{Yb}$ & 0.00 & 0.00 & 0.12 & 0.00 & 0.00 & 0.00 \\
\hline
\end{tabular}

homogeneity of the mineral. The composition of the fluocerite intergrowth was observed to vary slightly between different parts of the crystal. The intergrowth is, however, so fine-grained that separate phases could not be analysed.

Several partial chemical analyses from different parts of both the fluocerite and the bastnaesite phases were made. The results are shown in Table 2. Because detailed analytical determinations including carbon oxide and water, were not carried out, the chemical formulae of the minerals could not be calculated and only the content of REEs is compared in the present context. Ce, $\mathrm{La}$ and $\mathrm{Nd}$ are the main elements in the fluocerite intergrowth but the chemical composition shows slight variation. Ce is, however, dominant in all parts of the mineral. The $\mathrm{Ce} / \mathrm{La}$ ratio ranges from 1.3 to 1.8 within the fluocerite crystal as a result of separation of the different alteration phases.

The bastnaesite surrounding the fluocerite intergrowth is similarly enriched in Ce and other LREEs, La and Nd, but the compositional variation is not usually so high as in fluocerite. The mineral contains minute concentrations of $\mathrm{Y}$, which is almost lacking in fluocerite. The X-ray images and chemical analyses indicate that some per cents of $\mathrm{CaO}$ are locally present in bastnaesite. The REE ratios in both the fluocerite intergrowth and the bastnaesite are close to each other. Comparison of the REE ratios (the lower part of Table 2) shows that the bastnaesite is somewhat richer in $\mathrm{Nd}$ and poorer in La than the fluocerite intergrowth. Owing to the different chemical formula, the total content of REEs is, of course, smaller in bastnaesite.

The fluocerite intergrowth analysed has as an inclusion a small prismatic crystal of zircon that the secondary and backscattered electron images show to be heterogeneous. Some parts of it are altered and contain low concentrations of impurities. A partial microprobe analysis shows 3.2 wt $\% \mathrm{HfO}_{2}, 1.30$ wt $\% \mathrm{FeO}, 1.11$ wt $\% \mathrm{CaO}$, 0.63 wt $\%$ MnO, 0.17 wt $\% \quad \mathrm{Y}_{2} \mathrm{O}_{3}, 0.12$ wt $\%$ $\mathrm{Al}_{2} \mathrm{O}_{3}, 0.08$ wt $\% \quad \mathrm{Yb}_{2} \mathrm{O}_{3}$ and 0.05 wt $\% \quad \mathrm{Sc}_{2} \mathrm{O}_{3}$. The composition of the dark violet fluorite associated with the fluocerite intergrowth was also analysed. The mineral is an almost pure $\mathrm{Ca}$ fluoride containing traces of REEs $(0.11 \mathrm{wt} \%$ $\mathrm{La}_{2} \mathrm{O}_{3}, 0.08$ wt $\% \mathrm{Ce}_{2} \mathrm{O}_{3}$ and 0.03 wt $\% \mathrm{Yb}_{2} \mathrm{O}_{3}$ ).

\section{Discussion}

Natural rare earth trifluorides of $\mathrm{Ce}, \mathrm{La}$ and $\mathrm{Nd}$ that crystallize in the hexagonal system have been called fluocerite or tysonite in the literature. Steyn (1961) suggested that the original name fluocerite should apply to the uniaxial optically positive material that appears to be oxyfluorides 
on the basis of old analyses; the name tysonite should refer to the optically negative REE trifluorides. Later studies have shown that the criteria are not quite correct. Thoma and Brunton (1966) have shown that the optic character of synthetic REE trifluorides varies substantially with the composition. Further crystallographic studies reveal that the structure of the known REE oxyfluorides differs from that of fluocerite (Baenziger et al. 1954, Wells 1975). Nowadays the mineralogical literature prefers the name fluocerite, originally given to the mineral described by Berzelius from Sweden (from the granite pegmatites of Finnbo and Broddbo near Falun; see Geijer 1921) as early as 1845 . To date $\mathrm{Ce}$ and La dominant members of fluocerite are known in nature (see Chistyakova and Kazakova 1969, and Styles and Young 1983).

Fluocerite has been encountered as an accessory mineral in granites (Fel'dman et al. 1973), granite pegmatites (Geijer 1921; Heinrich and Gross 1960; Gurov et al. 1975), greisens (Popova and Bazhenova 1976), metasomatic rocks (Gurov and Gurova 1974), hydrothermal veins (Chistyakova and Kazakova 1969), eluvial deposits (Styles and Young 1983) and carbonatites (van Wambeke 1977). The associated minerals may be monazite, xenotime, RE-bearing fluorite, bastnaesite, cerianite, synchysite, samarskite, zircon, thorite, allanite or gadolinite.

After the Fjälskär fluocerite had been found, the mineral was also encountered in the heavy mineral fraction of the even-grained Saltvik rapakivi granite, Åland Islands (see Lindqvist and Suominen 1988, this volume). According to the records of the Mineralogical laboratory of the Geological Survey of Finland, cerianite has been identified with X-ray methods from the Väkkärä rapakivi granite, Eurajoki, western Finland, and fluocerite from the Parkkolansaari granite, Leppävirta, eastern Finland, but these observations have not been confirmed with chemical methods. Bastnaesite is known in Finland in several localities including certain types of rapakivi granite.

Fluocerite altered to cerianite or to bastnaesite
Table 3. Chemical analyses of the Fjälskär granite and associated rocks. The main constituents were analysed at the Research Centre of the Rautaruukki Company with XRF and the REEs at the Technical Research Centre of Finland with INAA methods.

\begin{tabular}{lrrrrrrr}
\hline & 1 & \multicolumn{1}{c}{2} & \multicolumn{1}{c}{3} & \multicolumn{1}{c}{4} & \multicolumn{1}{c}{6} & 7 \\
\hline $\mathrm{SiO}_{2}$ & 75.40 & 74.20 & 75.20 & 73.00 & 40.20 & 72.20 & 56.00 \\
$\mathrm{TiO}_{2}$ & 0.06 & 0.09 & 0.05 & 0.15 & 0.06 & 0.28 & 0.11 \\
$\mathrm{Al}_{2} \mathrm{O}_{3}$ & 13.50 & 13.20 & 13.70 & 13.70 & 37.00 & 13.80 & 22.30 \\
$\mathrm{FeOtot.}$ & 1.07 & 1.12 & 1.22 & 2.14 & 3.16 & 1.98 & 5.48 \\
$\mathrm{MnO}$ & 0.06 & 0.03 & 0.02 & 0.12 & 0.03 & 0.02 & 0.15 \\
$\mathrm{MgO}$ & 0.05 & 0.03 & 0.00 & 0.05 & 0.00 & 0.67 & 0.12 \\
$\mathrm{CaO}$ & 0.69 & 0.88 & 1.02 & 1.19 & 2.77 & 1.02 & 0.01 \\
$\mathrm{Na}_{2} \mathrm{O}$ & 3.33 & 3.19 & 3.58 & 3.33 & 2.44 & 2.03 & 1.99 \\
$\mathrm{~K}_{2} \mathrm{O}$ & 5.42 & 5.61 & 4.62 & 5.39 & 0.98 & 6.86 & 8.57 \\
$\mathrm{P}_{2} \mathrm{O}_{5}$ & 0.01 & 0.01 & 0.01 & 0.02 & 0.01 & 0.06 & 0.01 \\
\hline $\mathrm{Sum}$ & 99.60 & 98.35 & 99.41 & 99.09 & 86.65 & 98.91 & 94.74 \\
\hline
\end{tabular}

REE analyses

\begin{tabular}{lccccccc}
\hline & 1 & 2 & 3 & 4 & 5 & 6 & 7 \\
\hline $\mathrm{La}$ & 190 & 129 & 96 & 92 & 47 & 72 & 6.5 \\
$\mathrm{Ce}$ & 384 & 212 & 160 & 138 & 115 & 127 & 11 \\
$\mathrm{Nd}$ & 137 & 78 & 69 & 47 & 65 & 57 & 5.3 \\
$\mathrm{Sm}$ & 24 & 14.8 & 12.7 & 10.1 & 22 & 9.4 & n.d. \\
$\mathrm{Eu}$ & 1.29 & 0.38 & 0.61 & 0.24 & 0.79 & 1.29 & 0.05 \\
$\mathrm{~Tb}$ & 3.3 & 1.85 & 1.87 & 1.18 & 3.9 & 0.52 & 0.48 \\
$\mathrm{Yb}$ & 27 & 17.3 & 15.5 & 12.4 & 39 & 0.41 & 19.7 \\
$\mathrm{Lu}$ & 3.0 & 2.4 & 2.1 & 1.86 & 5.2 & 0.05 & 2.6 \\
$\mathrm{Sum} \mathrm{REE}$ & 768.82 & 455.73 & 357.78 & 302.78 & 297.89 & 267.67 & 45.63 \\
$\mathrm{Ce} / \mathrm{Yb}$ & 14 & 12 & 10 & 11 & 3 & 310 & 1 \\
\hline
\end{tabular}

1.-4. Granite, 5. Topaz-rich pegmatitic segregation,

6. Coarse-grained pegmatitic granite dyke,

7. Muscovite greisen dyke in granite.

has been reported in several studies (Oftedal 1931; Steyn 1961; Gurov and Gurova 1974; Gurov et al. 1975). A fluocerite-bastnaesitecerianite intergrowth similar to that in the Fjälskär granite has been described by Styles and Young (1983) from the altered eluvial monazite pebbles in the Afu Hills, Nigeria. The authors did not, however, describe the crystallography and chemistry of the intergrowth in detail.

Table 3 shows the analyses of the main elements and REEs from five specimens of the Fjälskär granite (1-5), from a cross-cutting pegmatitic granite dyke (6) and from a muscovite greisen dyke (7). The Fjälskär granite is a peraluminous syenogranite and its chemical compo- 
sition resembles certain rapakivi varieties (cf. Vorma 1976, Hapala 1977). Like rapakivi granites in general, the rock has exceptionally high concentrations of REEs, especially Ce, La and Nd (Koljonen and Rosenberg 1974; Vorma 1976). The Ce content is slightly higher than in rapakivi granites in general, and it may be up to four times the average Ce content of granite (cf. Haskin et al. 1968).

The LREEs are enriched in the Fjälskär granite mainly in fluocerite, bastnaesite, cerianite and fluorite; the HREEs are enriched in zircon. The REE distribution pattern of the Fjälskär fluocerite intergrowth resembles closely those described by Semenov and Barinskii (1958) from northern Kirgiziya, USSR, and by Heinrich and Gross (1960) from the Black Cloud pegmatite, Colorado, USA. Ce, La and $\mathrm{Nd}$ dominate in fluocerites and the sum of $\mathrm{La}+\mathrm{Ce}+\mathrm{Pr}$ always exceeds $70 \%$ of the total sum of REEs (Styles and Young 1983).

The alteration of fluocerite in the Fjälskär granite may be due to postmagmatic fluid activity. Hydrothermal solutions enriched in $\mathrm{CO}_{2}$ affected fluocerite and altered it to bastnaesite. The separation of a cerianite phase may be attributed to later oxidation of $\mathrm{Ce}^{3+}$ (in fluocerite and bastnaesite) to $\mathrm{Ce}^{4+}$ (in cerianite). Similar conclusions have previously been reached by Styles and Young (1983).

Bastnaesite and fluocerite are similar in struc- ture, and therefore syntaxial intergrowth between them is possible. Similarly, bastnaesite may occur as an intergrowth with parisite and roentgenite as described by Donnay and Donnay (1953). A photograph of a preferentially oriented fluocerite-REE fluorite intergrowth has been presented by Arkhangel'skaya (1970).

The results of X-ray single crystal studies from the Fjälskär fluocerite are in agreement with those of Oftedal (1931), who published a Laue photograph of a fluocerite-bastnaesite intergrowth and examined the structural similarities more closely. He showed that the a-axes of the minerals are identical and that they have a similar cation level after a period of $\mathrm{n} \times 14.6 \AA$ along the c-axis (that is $4 \times 1 / 2 \mathrm{c}_{\text {fluocerite }}=3 \times$ $1 / 2 c_{\text {bastnaesite }}$ ). To our knowledge, detailed studies of the fluocerite-bastnaesite intergrowth have not been reported since the study of Oftedal, and the present one is the first detailed X-ray diffraction study of the cerianite-fluocerite-bastnaesite intergrowth.

Acknowledgements. Dr. Olavi Kouvo first found the fluocerite from the heavy mineral fraction of the Fjälskär granite and kindly gave it to us for detailed studies. Bo Johanson did the microprobe determinations of the minerals and Jukka Keskinen and Mirja Saarinen helped with the Xray work. Prof. Atso Vorma, Dr. Kai Hytönen and Mr. Kristian Lindqvist kindly read the manuscript and offered constructive criticism. Mrs. Gillian Häkli corrected the English of the manuscript. We are grateful to all these persons for their co-operation and help.

\section{References}

Arkhangel'skaya, V. V., 1970. Dissociation textures of a solid solution in natural rare-earth fluorite. Dokl. Akad. Sci. U.S.S.R. Earth Sci. Sect. 195, 142-145.

Baenziger, N. C.; Holden, J. R.; Knudson, G. E. \& Popov, A. I., 1954. Unit cell dimensions of some rare earth oxyfluorides. J. Am. Chem. Soc. 76, 4734-4735.

Bergman, L., 1986. Structure and mechanism of intrusion of postorogenic granites in the archipelago of southwestern Finland. Acta Acad. Aboensis B, Math. et Phys. 45(5), 74 p.

Chistyakova, M. B. \& Kazakova, M. E., 1969. Flyuotserit iz Kazahstana. Akad. Nauk SSSR. Trudy Min. Muz. 19, $236-238$.

Donnay, G. \& Donnay, J. D. H., 1953. The crystallography of bastnaesite, parisite, roentgenite, and synchisite. Am. Mineral. 38, 932-963.

Ehlers, C. \& Bergman, L., 1984. Structure and mechanism of intrusion of two postorogenic granite massifs, southwestern Finland. In Kröner, A. and Greiling, R. (eds.) Precambrian tectonics illustrated. E. Schweitzerbart'sche Veriagsbuchhandlung (Nägele u. Obermiller), Germany, Stuttgart, pp. 173-190. 
Fel'dman, L. G.; Surkov, B. K. \& Stolyarova, T. I., 1973. Flyuotserit iz redkometal'nyh granitov severnogo Tyan'shchanya i nekotory dannye k geneticheskoj mineralogii ftoridov redkozemel'nyh elementov. Akad. Nauk SSSR, Trudy Min. Muz. 22, 143-158.

Geijer, P., 1921. On fluocerite and tysonite. Geol. Fören. Stockh., Förh. 43, 19-23.

Gurov, E. P. \& Gurova, E. P., 1974. Flyuotserit iz metasomatichskih porod ukrainskogo kristallicheskogo shchita. Mineral. Zametki 28: 4, 41-43.

-, Gurova, E. P.; Loginova, L. G. \& Labitskaya, Y. A., 1975. Flyuotserit iz pegmatitov i metasomatitov SevernoZapadnoj tsasti ukrainskogo shchita. Zap. Vses. Min. Obshch. 104, 455-458.

Haapala, I., 1977. Petrography and geochemistry of the Eurajoki stock, a rapakivi-granite complex with greisen-type mineralization in southwestern Finland. Geol. Surv. Finland, Bull. 286, 128 p.

Haskin, L. A.; Haskin, M. A.; Frey, F. A. \& Wildeman, T. $R ., 1968$. Relative and absolute terrestrial abundances of the rare earths. In Ahrens, L. H. (ed.) Origin and Distribution of the Elements Pergamon Press, pp. 889-912.

Heinrich, E. W. \& Gross, E. B., 1960. Fluocerite and associated minerals from the Black Cloud pegmatite, Teller County, Colorado. Am. Mineral. 45, 455-459.

Jansen, G. J.; Magin, G. B. Jr. \& Levin, P., 1959. Synthesis of bastnaesite. Am. Mineral. 44, 180-181.

Koljonen, T.\& Rosenberg, R. J., 1974. Rare earth elements in granitic rocks. Lithos 7, 249-261.

Lindqvist, K. \& Suominen, V., 1988. Cerussite from even grained rapakivi, Saltvik, Alland Islands, SW Finland. Bull. Geol. Soc. Finland 60, 00-00.

Oftedal, I., 1931. Über die Parallelverwachsung von Tysonit und Bastnäsit. Norsk Geol. Tidsskr. 12, 459-467.
Popova, V. I. \& Bazhenova, L. F., 1976. Pervaya nahodka flyutserita na Dal'nem Vostoke. Akad. Nauk. S.S.S.R. Vses. Min. Obshch. 135-138.

Sederholm, J. J., 1934. On migmatites and associated PreCambrian rocks of southwestern Finland III. The Åland Islands. Bull. Comm. Geol. Finlande 107, 68 p.

Semenov, E. I. \& Barinskii, R. L., 1958. The composition characteristics of the rare earths in minerals. Geochemistry 1958, 398-419.

Steyn, J. G. D., 1961. Tysonite from Mutue Fides. Geol. Surv., Union of South Africa, Bull. 35, 31 p.

Styles, M. T. \& Young, B. R., 1983. Fluocerite and its alteration products from the Afu Hills, Nigeria. Mineral. Mag. $47,41-46$.

Suominen, V., 1988 (in prep.) The chronostratigraphy of southwestern Finland with special reference to the Postjotnian and Subjotnian diabases. Geol. Surv. Finland, Bull.

Thoma, R. E. \& Brunton, G. D., 1966. Equilibrium dimorphism of the lanthanide trifluorides. Inorg. Chem. 5, 1937-1939.

Wambeke, van, L., 1977. The Karonge rare earth deposits, Republic of Burundi: New mineralogical-geochemical data and origin of the mineralization. Mineral. Deposita 12, $373-380$.

Vorma, A., 1976. On the petrochemistry of rapakivi granites with special reference to the Laitila massif, southwestern Finland. Geol. Surv. Finland, Bull. 285, 98 p.

Wells, A. F., 1975. Structural inorganic chemistry. Clarendon Press, Oxford. 1095 p.

Received January 13, 1988

Revised and accepted February 11, 1988 